\title{
Kernwapens en Suid-Afrika
}

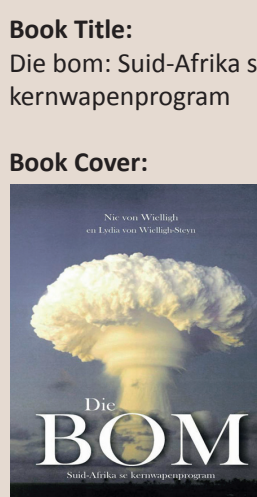

Authors:

Nic von Wielligh

Lydia von Wielligh-Steyn

\section{ISBN:}

978-1-920188-47-4

\section{Publisher:}

Litera Publikasies, Hatfield,

Pretoria, 2014, R385*

*Book price at time of review

$\square$

Review Title:

Kernwapens en Suid-Afrika

Reviewer:

Waldo Stumpf ${ }^{1}$

\section{Affiliation:}

${ }^{1}$ Department of Materials Science and Metallurgical Engineering, University of Pretoria, South Africa

Email:

waldo.stumpf@up.ac.za

Postal address:

Van Wouw Street 102 Groenkloof, Pretoria 0181,

South Africa

How to cite this book review: Stumpf, W., 2015,

'Kernwapens en Suid-Afrika',

Suid-Afrikaanse Tydskrif vir Natuurwetenskap en Tegnologie 34(1), Art. \#1287, 3 pages. http:// dx.doi.org/10.4102/satnt. v34i1.1287

\section{Read online:}

In 'n lekkerleesboek het Nic von Wielligh en sy dogter Lydia von Wielligh-Steyn 'n baie groot, maar ook nodige taak aangepak om Suid-Afrika se veelbewoë ontwikkeling van eie kernwapenvermoë te boekstaaf. 'n Groot aantal artikels plaaslik en oorsee en selfs 'n boek of twee het die onderwerp al gedeeltelik toegelig. Hierdie weergawe van meer as 500 bladsye gee egter die mees omvattende blik tot dusver op die politieke gebeure, asook die wetenskaplike mylpale wat eerstens tot die program se ontwikkeling, maar later ook aftakeling gelei het. Suid-Afrika bly tot vandag toe nog die enigste land ter wêreld wat sy kernwapenvermoë ontwikkel het, maar dit dan vrywillig afgetakel het om as 'n kernwapenvrye land tot die VN se Kernsperverdrag toe te tree. Dit is voorwaar 'n 'storie om te vertel' waarin die skrywers op 'n lekker leesbare manier uitmuntend daarin geslaag het om dit vir sowel die ingeligte leser, asook die leek vas te lê as 'n stuk van ons land se geskiedenis in die reis van 'muishond van die wêreld' tot 'n geëerde lid van die internasionale gemeenskap.

Hierdie 'storie' in ons land se geskiedenis kan nie losgemaak word van die politieke gebeure die afgelope vyf tot ses dekades nie. Dit is dus nie verrassend dat die program deur al die jare, ondanks streng geheimhouding tot Maart 1993 (toe dit amptelik in die parlement bekend gemaak is), sterk emosies daarvoor sowel as daarteen ontlok het nie. Baie het dit gesien as ons land en sy mense se vermoë om die wêreld vierkantig in die oë te kyk en te sê: 'Ons sal die wêreld wys wat ons self kan doen.' Ander - die groot meerderheid - het die moraliteit en koste van so 'n program sterk bevraagteken en veroordeel, al is daar destyds nog net vermoed dat dit wel bestaan. Om die 'storie' teen hierdie agtergrond sinvol en ook gemaklik te vertel, het die skrywers die emosies 'vir' en 'teen' suksesvol omseil. Eerstens is die verteltrant deurgaans neutraal en verhalend, wat dit aangenaam en boeiend laat lees. Tweedens word daar op gepaste wyse telkens ' $n$ terugflits gegee ten opsigte van die wetenskaplike ontdekkings in die wêreld van die verlede wat bygedra het om die legkaart vir die mensdom te voltooi. Dit beteken egter nie dat dié werk ligtelik met die waarheid omgaan nie. Elke insident of bydraende ontwikkeling van die vroeë gebeure van ontdekkings deur reuse in die wetenskap soos Niels Bohr en vele andere, maar ook die opbou asook aftakeling van die plaaslike kernvermoë is noukeurig nagevors en van betroubare bronne voorsien. Verder word regeringsdokumente uit argiewe ingesluit wat vroeër as 'Geheim' of selfs 'Uiters Geheim' geklassifiseer is en wat die leser 'n blik gee op die raamwerk waarbinne regeringsbesluite oor hierdie program destyds geneem is.

Die breë wetenskaplike agtergrond van die vroeër jare van die 20ste eeu waarbinne die wêreld stadig maar seker tot by die 'wapen van alle tye' gevorder het, vind beslag in die titel van die boek (Die bom) terwyl Suid-Afrika se ontwikkeling slegs tot by ses kerntoestelle gevorder het. Daar was nooit aflewerbare 'bomme' nie en dit was trouens ook nooit die doel nie. Die destydse regering het terdeë besef dat die gebruik van so ' $n$ 'wapen' teen eie of naburige bevolkingsgroepe 'selfmoord' sou meebring deurdat ons groot stede binne weke deur die groot moondhede platgevee sou word. Die skrywers slaag baie goed daarin om Suid-Afrika se beperkte kernvermoë binne 'n veel breër wêreldvermoë te plaas wat uiteindelik tot die onsinnige kernwapenwedloop tussen die Verenigde State van Amerika (VSA) en die vroeëre Sowjetunie gelei het. Dit word gedoen deur die leser op 'n natuurlike wyse deur die verskillende fases van die wêreld se 'ontdekking' tot by 'ontwikkeling', 'aanwending' en uiteindelik ook tot by 'besinning' te neem in die gebruik van die geweldige atoomkragte wat in ons skepping opgesluit lê.

In Deel 1 van die werk is die 'Diffusie van kennis', die eerste fase waarin die wetenskap geleidelik en met rukke en stote beweeg het tot die ontrafeling van die atoom se enorme interne kragte;'n proses van kennisverspreiding wat nooit omgekeer sou kon word nie. Dat verskeie wetenskaplikes van daardie vroeë jare al ongemaklik begin word het oor wat die mensdom met dié kennis sou kon aanvang, spreek boekdele. Leo Szilard het in 1934 al 'n volhoubare kettingreaksie by kernsplyting voorspel en enkele jare later, nadat sy teorie deur hom en Walter Zinn onder leiding van Enrico Fermi op U-235 bewys is, het hy sy publikasie van hierdie resultate eers teruggehou, want, het hy

Copyright: @ 2015. The Authors. Licensee: AOSIS OpenJournals. This work is licensed under the Creative Commons Attribution License. 
gesê: 'There was very little doubt in my mind that the world was headed for grief' (p. 19).

Daarna skets die werk 'n fase van 'oorlogsgedrewe haas' om hierdie wetenskap tot ' $n$ aanwendbare wapen te ontwikkel. Die 'Manhattan Project' in die VSA wat hierdie opdrag te midde van 'n toenemende tweede wêreldkonflik moes uitvoer, staan vandag nog bekend as een van die mees ambisieuse nywerheidsprojekte in die geskiedenis. Dit, terwyl die geskiedenis nou nog verdeeld is of die verskrikking van Hirosjima en Nagasaki werklik nodig was om Japan se oorgawe af te dwing (bl. 42). Was Japan nie destyds tog op die rand van oorgawe nie? Dié vraag lê vandag nog op die wêreld se gewete, maar 'n eenduidige antwoord is nie vanselfsprekend nie.

In Deel 2 van die werk volg 'n uiteensetting van 'n volgende fase waarin die mensdom 'tot besinning probeer $\mathrm{kom}^{\prime}$ en hierdie 'monster' probeer tem met internasionale ooreenkomste soos die Kernsperverdrag (KSV) wat die wêreld verdeel het in die groot vyf: 'wat het' aan die een kant en die res ('wat nie het nie') aan die ander kant. Dat so 'n verdelende ooreenkoms 'n resep was (en nog is) vir lande soos Iran, Irak (vroeër onder Saddam Hussein) en NoordKorea om binne die KSV te probeer oorbeweeg na dié 'wat het', was seker voorspelbaar. Dat dit ook lande buite die KSV sou wou hou, soos Suid-Afrika destyds, asook Israel, Indië en Pakistan vandag nog, is seker ook te verstane. Sou enige ander verdrag ' $n$ beter oplossing kon gebied het? Sekerlik nie - dit was 'n produk van sy tyd! Die werk noem dit tereg "n moeilike balanseertoertjie' (bl. 72).

Saam met die fase waar die wêreld probeer om die 'monster' te beheer, volg ook 'n fase van 'internasionale gekheid' tydens die Koue Oorlog. Waarom die kernarsenale van die Sowjetunie destyds moes toeneem tot 45000 en die VSA tot 23000 kernwapens in die 1980's (waarvan vele ordegroottes sterker was as dié wat in Japan gebruik is), is onbegryplik. Op bladsy 55 in die werk word dit tereg beskryf as 'n wedloop van 'groter en beter' en 'meer' sonder einde!

Met Deel 1 en 2 as insiggewende agtergrond betree die skrywers in Deel 3 die veelbesproke, maar tog nog meer beskeie Suid-Afrikaanse kernprogram met 'n gepaste opskrif 'Die bom in diebosveld'. Dat die Pelindaba-aanlegjuis gevestig was op die plaas wes van Pretoria waar die bekroonde digter en wetenskaplike, Eugene Marais, ook tot sy tragiese einde gekom het, gee tog so 'n tikkie ironie aan die werk onder die opskrif, "n Droewige gebeurtenis op die plaas Pelindaba' op bl. 103 van die boek. Dit is hier waar die eerste gedagtes by vroeë wetenskaplikes soos Ampie Roux, Wally Grant, Wynand de Villiers en andere ontstaan het om vreedsame waarde toe te voeg tot Suid-Afrika se uraanuitvoere deur dit in U-235 te verryk. Ironies genoeg is baie van hierdie wetenskaplikes in die VSA opgelei in Eisenhower se mislukte 'Atoms for Peace'-program wat selfs 'vreedsame kernontploffings vir nywerheidsgebruik' voorsien het. Dié opleiding was waarlik deel van die proses van 'diffusie van kennis'!
Die leser word dan stelselmatig geneem deur die om wenteling van die program van aanvanklik 'n 'vreedsame' doelwit af na een wat deur politieke botone ingekleur word; veral met die intrek van Kubaanse magte in Angola in die middel- tot laat-1970's en verskerpte druk vanuit die buiteland, veral op diplomatieke gebied vanuit die VSA, maar ook deur middel van verskerpte militêre optrede op Suid-Afrika se grense deur die lande van die Warskouverdrag. Hier het Suid-Afrika se eie 'Manhattan-projek in die kleine', die Y-aanleg vir hoogverryking, tot stand gekom. Ons eie fase van 'oorlogsgedrewe haas'? Dié deel van die werk gee ' $n$ interessante blik in die tegniese, maar ook die menslike uitdagings wat op die destydse Valindaba oorkom is om hierdie gevorderde aanleg in werking te kry. Die menslike wel en wee by so 'n program wat in die geheim opgerig en bedryf moes word, maak van hierdie werk veel meer as net nog 'n tegniese verhaal wat al herhaaldelik elders beskryf is.

Die leser word in Deel 3 ook blootgestel aan 'n anomalie in beleid wat al dikwels deur kundiges uitgewys is, selfs deur die Internasionale Atoomenergie-agentskap (IAEA) en die internasionale verifikasiespan wat in 1993 'n opvolgondersoek gedoen het. Dit is dat dit die regering, by monde van Meneer P.W. Botha se duidelike besluit was dat hierdie program nooit die gebruik van taktiese kernwapens sou insluit nie en dat die toestelle slegs as 'n politieke afweermiddel sou dien, aangesien taktiese gebruik as 'n wapen 'selfmoord' vir die land sou beteken. Daarteenoor was daar veral binne Krygkor 'n duidelike program om die toestelle verder te ontwikkel en te verklein tot missielaflewerbare grootte. Hierdie teenstrydigheid in strategiese beleid is in September 1985 in geen onduidelike terme deur Meneer P.W. Botha self tot ' $n$ halt geroep toe hy bevestig het dat die land se kernvermoë beperk sou wees tot sewe toestelle alleen en geen werklike 'kernwapens' daaruit sou voortvloei nie. Was hierdie anomalie dalk amper Suid-Afrika se 'oomblik van waansin'?

In Deel 3 breek Suid-Afrika se eie fase van 'besinning' ook aan en kom die program se einde in sig, veral gedryf deur die politieke ontspanning op ons land se grense ná die ineenstorting van die voormalige Sowjetunie. Dit het ook 'n ongekende ommekeer in Suid-Afrika se interne politieke bestel, gelei deur Meneer F.W. de Klerk, meegebring. Hierdie gebeure het vanselfsprekend 'n ingrypende gevolg vir die inheemse kernprogram ingehou wat uiteindelik, na vele internasionale en plaaslike uitdagings met die aftakeling en daarna die verifiëringsproses, uitgeloop het op die erkenning dat Suid-Afrika vandag nog internasionaal as 'n model voorgehou word om op sowel die politieke terrein as op dié van nieverspreiding van kernwapens eie belange ter syde te stel en te doen 'wat reg is'. Die oproepe van al drie Bybelse profete - Jesaja, Joël en Miga - om 'ons swaarde te omvorm in ploegskare' het waarlik hier ingetree.

In die proses van 'nasionale, maar ook internasionale normalisering' in die land se kerntoekoms het Nic von Wielligh persoonlik 'n groot aandeel gehad en om die 'verhaal' op so 'n lekker leesbare manier saam met sy dogter, 
Lydia von Wielligh-Steyn, te boekstaaf, is 'n onderskeiding waarvoor alle Suid-Afrikaners wat in ons land se geskiedenis belangstel, hulle sal eer. Die ietwat lywige boek wat tog spannend en pittig lees, is een wat op elke Suid-Afrikaner se boekrak behoort te staan. 'n Vertaling in Engels sal seker sy internasionale trefwydte verhoog, maar die lekker, tipies geestige en pittige sêgoed wat so mooi in Afrikaans oor ' $n$ mens se tong gly, mag nie in so 'n vertaling verlore gaan nie. 